\title{
Cinnamicaldehyde regulates the expression of tight junction proteins and amino acid transporters in intestinal porcine epithelial cells
}

Kaiji Sun ${ }^{1}$, Yan Lei ${ }^{2}$, Renjie Wang ${ }^{1,2}$, Zhenlong $\mathrm{Wu}^{1,4^{*}}$ and Guoyao $\mathrm{Wu}^{1,3}$

\begin{abstract}
Background: Cinnamicaldehyde (CA) is a key flavor compound in cinnamon essential oil possessing various bioactivities. Tight junction (TJ) proteins are vital for the maintenance of intestinal epithelial barrier function, transport, absorption and utilization of dietary amino acids and other nutrients. In this study, we tested the hypothesis that CA may regulate the expression of TJ proteins and amino acid transporters in intestinal porcine epithelial cells (IPEC-1) isolated from neonatal pigs.

Results: Compared with the control, cells incubated with $25 \mu \mathrm{mol} / \mathrm{L}$ CA had increased transepithelial electrical resistance (TEER) and decreased paracellular intestinal permeability. The beneficial effect of CA on mucosal barrier function was associated with enhanced protein abundance for claudin-4, zonula occludens (ZO)-1, ZO-2, and ZO-3. Immunofluorescence staining showed that $25 \mu \mathrm{mol} / \mathrm{L}$ CA promoted the localization of claudin-1 and claudin-3 to the plasma membrane without affecting the localization of other TJ proteins, including claudin-4, occludin, ZO-1, ZO-2, and ZO-3, compared with the control cells. Moreover, protein abundances for rBAT, XCT and LAT2 in IPEC-1 cells were enhanced by $25 \mu \mathrm{mol} / \mathrm{L}$ CA, while that for EAAT3 was not affected.

Conclusions: CA improves intestinal mucosal barrier function by regulating the distribution of claudin-1 and claudin-3 in enterocytes, as well as enhancing protein abundance for amino acid transporters rBAT, xCT and LAT2 in enterocytes. Supplementation with CA may provide an effective nutritional strategy to improve intestinal integrity and amino acid transport and absorption in piglets.
\end{abstract}

Keywords: Amino acid transporters, Barrier function, Cinnamicaldehyde, Intestinal epithelial cells, Tight junction proteins

\section{Background}

Cinnamicaldehyde (CA) is a key flavor compound in cinnamon essential oil extracted from the stem bark of Cinnamomum cassia in nature [1]. CA is widely used in the perfume, pharmacy, and food processing industries due to its antioxidant, anti-microbial, and anti-diabetic properties [2-6]. Moreover, it has been reported that CA has chemotherapeutic and anticancer effects through the inhibition of proliferation, inducing apoptosis, and blocking angiogenesis [7-9]. Importantly, CA is a safe flavor compound approved by FDA and the 'Flavor and Extract

\footnotetext{
* Correspondence: bio2046@hotmail.com

'State Key Laboratory of Animal Nutrition, College of Animal Science and

Technology, China Agricultural University, Beijing 100193, China

${ }^{4}$ Department of Animal Nutrition and Feed Science, China Agricultural

University, Beijing 100193, China

Full list of author information is available at the end of the article
}

Manufacturers' Association of the United States, suggesting the potential administration of this dietary factor may be achievable within an acceptable safety range for humans and animals [5]. The well documented antimicrobial properties and safety of CA have promoted its application to the nutrition of humans and animals. It has been reported that supplementation of essential oils, in which CA is the major component, increases the digestibility of crude protein in weaned pigs [10]. The beneficial effects of CA are associated with the enhanced secretion of digestive enzymes, improved nutrient digestion, and enhanced feed intake [11-14]. It remains unknown whether $C A$ has any effect on intestinal barrier function, as well as nutrient transport and absorption in humans and pigs.

The epithelial barrier is formed by the apical plasma membrane and intercellular tight junction (TJ), which provides physical and functional barriers to prevent bacteria, 
endotoxins and other harmful substances from entering the blood circulation, while also allowing for the absorption of nutrients [15]. Diverse physiological or pathological stimuli can regulate the intestinal mucosal-barrier function, which contributes to nutrient transport, absorption, and intracellular homeostasis [16-19]. Consistently, dysfunction of TJ proteins has been reported to be associated with increased paracellular permeability, and the development and progression of multiple intestinal disorders [20].

Although CA is known to improve the digestibility of dietary fiber, lipids, and crude protein, the underlying cellular and molecular mechanisms remain largely unknown. We have hypothesized that CA may up-regulate the expression of $\mathrm{TJ}$ proteins and amino acid transporters in intestinal epithelial cells, thus contributing to the intestinal barrier function in neonates. This hypothesis was tested in the present study using porcine intestinal epithelial cells (IPEC-1), isolated from neonatal pigs.

\section{Methods}

\section{Reagents}

Dulbecco's modified Eagle's F12 Ham medium (DMEMF12) and fetal bovine serum (FBS) were purchased from Invitrogen (Carlsbad, CA, USA). Epidermal growth factor was a product of BD Biosciences (Carlsbad, CA, USA). Trypsin/EDTA was procured from Gibco (Carlsbad, CA, USA). Antibodies against occludin, claudin-1, claudin3 , claudin-4, zonula occludens (ZO)-1, ZO-2, and ZO-3 were products of Invitrogen (Carlsbad, CA, USA). Unless indicated, all other chemicals including CA were purchased from Sigma-Aldrich (St. Louis, MO, USA).

\section{Cell culture}

Intestinal porcine epithelial cell line 1 (IPEC-1) cells, which were isolated from the jejunum of newborn pigs without access to milk or any food [21], were then cultured in a DMEM-F12 medium supplemented with $5 \%$ FBS, insulin $(5 \mu \mathrm{g} / \mathrm{mL})$, transferrin $(5 \mu \mathrm{g} / \mathrm{mL})$, selenium (5 ng/mL), epidermal growth factor $(5 \mu \mathrm{g} / \mathrm{L})$, penicillin $(50 \mu \mathrm{g} / \mathrm{mL})$ and streptomycin $(4 \mu \mathrm{g} / \mathrm{mL})$ as previously described [22]. All cell cultures were carried out at $37{ }^{\circ} \mathrm{C}$ in a humidified incubator containing $5 \% \mathrm{CO}_{2}$.

Measurement of transepithelial electrical resistance (TEER) The tightness of the TJ was assessed by measuring TEER as previously described [23]. Briefly, IPEC-1 Cells $\left(5 \times 10^{4}\right.$ cells per well $)$ were seeded in culture transwells (the membrane area, $0.33 \mathrm{~cm}^{2}$; pore size, $0.4 \mu \mathrm{m}$ ) which were placed in 24-well culture plates. Cells were incubated with $0,12.5$, or $25 \mu \mathrm{mol} / \mathrm{L}$ CA for the indicated time periods. TEER was determined every $12 \mathrm{~h}$ by using a Millicell ERS-2 Voltage-Ohm Meter (World Precision Instruments) equipped with a STX01 electrode as described here [24]. All values are expressed as percentages of the basal level for the controls.

\section{Monolayer paracellular permeability determination}

Paracellular permeability was determined as previously described [25]. Briefly, IPEC-1 cells were seeded in culture transwells as for TEER determination. $1 \mathrm{mg} / \mathrm{mL}$ FITCdextran $(20 \mathrm{kDa})$ was added to the apical side of the monolayer and the flux of FITC-dextran was determined by serially sampling the basolateral compartment every $12 \mathrm{~h}$. The concentration of FITC-dextran was measured using the SpectraMax M3 Multi-Mode Microplate Reader (Molecular Devices) with excitation and emission wavelengths of 490 and $520 \mathrm{~nm}$, respectively. The permeability of monolayer cells was defined as the amount of FITC-dextran that was transported from the apical side into the basolateral chamber. FITC-dextran concentration was calculated by subtracting the fluorescence value of the FITC-free medium.

\section{Western blot analysis}

IPEC-1 cells treated with various concentrations of CA for $24 \mathrm{~h}$ were harvested for the analysis of the abundance of TJ proteins, as previously described [24]. Equal amounts of proteins $(25 \mu \mathrm{g})$ were separated on SDSPAGE gels, transferred to polyvinylidene difluoride membranes (Millipore), and then incubated with a primary antibody $(1: 2,000)$ overnight at $4{ }^{\circ} \mathrm{C}$ and then incubated with an appropriate secondary antibody $(1: 2,000)$ at $25^{\circ} \mathrm{C}$ for $1 \mathrm{~h}$. The blots were detected with the Image Quant LAS 4000 mini system (GE Healthcare Bio-sciences AB, Inc., Sweden) after incubation with the ECL plus system (Amersham Biosciences, Sweden). Chemifluorescence was quantified with the use of the Quantity One software (BioRad Laboratories). All results were normalized to GAPDH and expressed as relative values to those of the control group.

\section{Immunofluorescence assay}

IPEC-1 cells treated with or without CA were fixed with $4 \%$ paraformaldehyde at $37^{\circ} \mathrm{C}$ for $20 \mathrm{~min}$, and then were incubated with a specific primary antibody against claudin-1, claudin-3, claudin-4, ZO-1, ZO-2 and ZO-3 for $16 \mathrm{~h}$ at $4{ }^{\circ} \mathrm{C}$. Cells were washed three times with PBS, and then were incubated with an appropriate secondary antibody $(1: 100)$ for $1 \mathrm{~h}$ at $25{ }^{\circ} \mathrm{C}$. Nuclei were stained by using Hoechst $33258(1 \mu \mathrm{g} / \mathrm{mL})$ for $10 \mathrm{~min}$ at $25{ }^{\circ} \mathrm{C}$. The distribution of TJ proteins was visualized under a fluorescence microscope (Axio Vert. A1, Zeiss, Germany).

\section{Statistical analysis}

Values are expressed as mean \pm SEM. Data was analyzed by one-way ANOVA and the Student-Newman-Keuls multiple comparisons test, using the SPSS statistical software 
(SPSS for Windows, version 17.0). $P \leq 0.05$ were taken to indicate statistical significance.

\section{Results}

Effects of CA on barrier function in the IPEC-1 cell monolayer

As shown, incubation of cells with $25 \mu \mathrm{mol} / \mathrm{L}$ CA led to greater $(P<0.05)$ TEER at $36-48 \mathrm{~h}$ (Fig. 1a) when compared with controls. In contrast, no difference was observed between the cells treated with $12.5 \mu \mathrm{mol} / \mathrm{L} \mathrm{CA}$ and the control cells at 12-48 h. Consistent with increased TEER, cells incubated with $25 \mu \mathrm{mol} / \mathrm{L}$ CA had reduced $(P<0.05)$ paracellular permeability, as indicated by FITCdextran flux at 12-48 h (Fig. 1b) when compared with controls. Cells treated with $12.5 \mu \mathrm{mol} / \mathrm{L} \mathrm{CA}$ had lowered

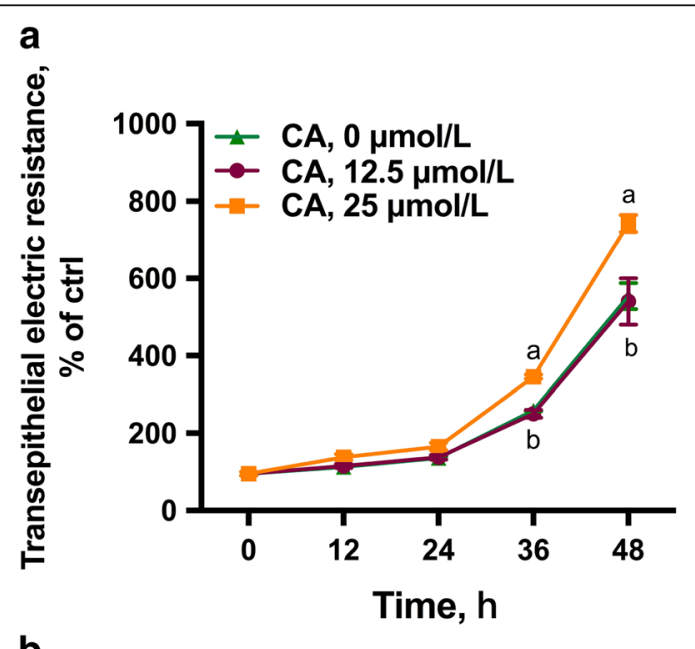

b

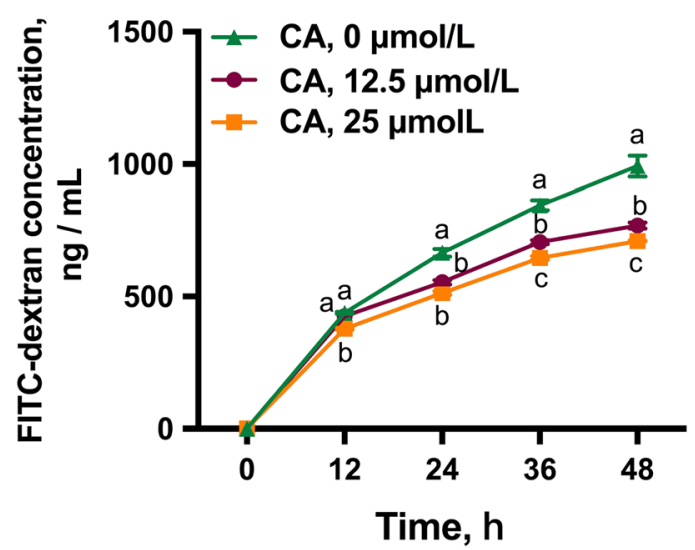

Fig. 1 Effects of CA on intestinal barrier function in IPEC-1 cells. Cells were cultured for $24 \mathrm{~h}$ in the absence or presence of 12.5 - or $25 \mu \mathrm{mol} / \mathrm{L}$ CA. a TEER and $\mathbf{b}$ paracellular permeability were then determined. Values are expressed as means \pm SEM, $n=6$. Means at a time point without a common letter differ, $P<0.05$. CA, Cinnamicaldehye; IPEC-1, intestinal porcine epithelial cell line 1; TEER, trans-epithelial electrical resistance permeability $(P<0.05)$, compared with the control cells at 24-48 h. Although both 12.5 and $25 \mu \mathrm{mol} / \mathrm{L}$ CA treatment led to decreased permeability in enterocytes compared with the controls, cells treated with $25 \mu \mathrm{mol} / \mathrm{L}$ CA had lower permeability $(P<0.05)$ when compared with cells incubated with $12.5 \mu \mathrm{mol} / \mathrm{L} \mathrm{CA}$ at $36-48 \mathrm{~h}$.

\section{Effects of CA on expression of TJ proteins in IPEC-1 cells} Compared with control cells, $25 \mu \mathrm{mol} / \mathrm{L}$ CA enhanced $(P<0.05)$ the abundance of proteins for claudin-4 (Fig. 2c) and $\mathrm{ZO}$ family proteins including $\mathrm{ZO}-1, \mathrm{ZO}-2$, and $\mathrm{ZO}-3$ (Fig. 3). The protein abundance for ZO-2 (Fig. 3b), instead of other proteins, was enhanced by $12.5 \mu \mathrm{mol} / \mathrm{L} \mathrm{CA}$ $(P<0.05)$ compared with that of the control. The protein abundances for claudin-1(Fig. 2a), claudin-3 (Fig. 2b), and occludin (Fig. 2d) were not affected $(P>0.05)$ by 12.5 or $25 \mu \mathrm{mol} / \mathrm{L}$ CA treatment.

\section{Effects of CA on the intracellular distribution of $\mathrm{TJ}$ proteins in IPEC-1 cells}

The cellular distributions of TJ proteins were assessed by an immunofluorescence microscope. Treatment with $25 \mu \mathrm{mol} / \mathrm{L}$ CA promoted the localization of claudin-1 and claudin-3 (Fig. 4a and b) to the plasma membrane without affecting the localization of other $\mathrm{TJ}$ proteins, including claudin-4, occludin, ZO-1, ZO-2, and ZO-3, compared to the control cells (Fig. 4). In contrast, $12.5 \mu \mathrm{mol} / \mathrm{L} \mathrm{CA}$ had no effect on the localization of TJ proteins determined in our study, such as claudin-1, claudin-3, claudin-4, occludin, ZO-1, ZO-2, and ZO-3 (Fig. 4). It should be noted that most of the ZO-3 was located at the nucleus membrane which was not affected by CA exposure (Fig. 4g).

\section{Effects of CA on the protein abundance for amino acid transporters}

The active transport of amino acids is the major mechanism for their uptake into enterocytes [26-28]. We determined the protein abundance for the following amino acid transporters, EAAT3 (high-affinity glutamate transporter), LAT2 (arginine and leucine transporter), rBAT (basic amino acid transporter), and $\mathrm{xCT}$ (acidic amino acid transporter) in IPEC-1 cells by Western blot analysis. The protein abundance for rBAT (Fig. 5a) and LAT2 (Fig. 5c) in IPEC-1 cells were enhanced $(P<0.05)$ by both 12.5 - and $25 \mu \mathrm{mol} / \mathrm{L} \mathrm{CA}$, compared with the control cells. In contrast, $25 \mu \mathrm{mol} / \mathrm{L}$ CA increased $(P<0.05)$ the protein abundance for $\mathrm{xCT}$ in the intestinal epithelial cells, but $12.5 \mu \mathrm{mol} / \mathrm{L}$ CA had no effect (Fig. 5b). The protein abundance for EAAT3 was not affected $(P>0.05)$ by either 12.5 or $25 \mu \mathrm{mol} / \mathrm{L} \mathrm{CA}$ (Fig. 5d), compared with the control cells. 


\section{a}
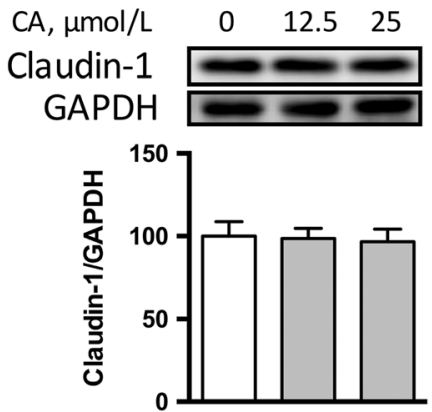

b
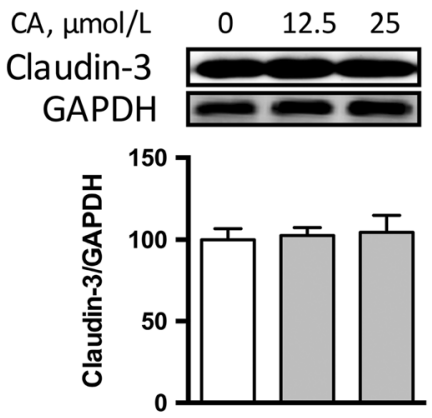

C
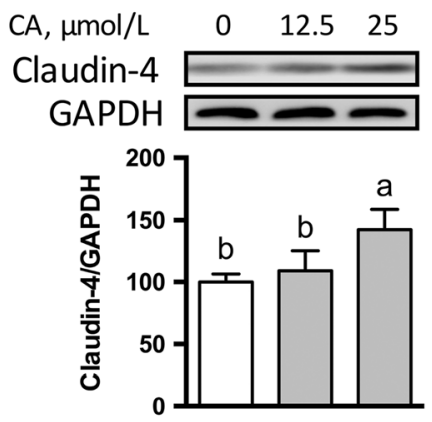

d
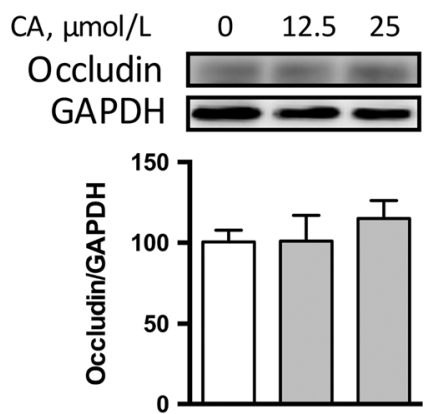

Fig. 2 Protein abundances for claudin-1 (a), claudin-3 (b), claudin-4 (c), and occludin (d) in IPEC-1 cells. IPEC-1 cells were cultured in the absence or presence of 12.5 or $25 \mu \mathrm{mol} / \mathrm{L}$ CA for $24 \mathrm{~h}$. Cells were collected and protein abundances were analyzed. Values are expressed as means $\pm \mathrm{SEM}, n=3$. Means without a common letter differ, $P<0.05$. CA, Cinnamicaldehyde; IPEC-1, intestinal porcine epithelial cell line 1

\section{a}

$\mathrm{CA}, \mu \mathrm{mol} / \mathrm{L} \quad 0 \quad 12.5 \quad 25$

$\mathrm{ZO}-1 \div$

GAPDH $\rightleftharpoons$

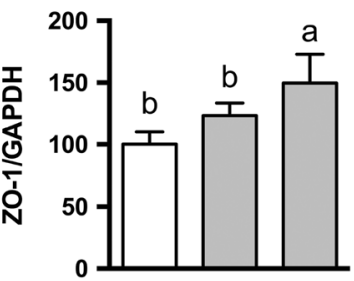

b

$\mathrm{CA}, \mu \mathrm{mol} / \mathrm{L} \quad 0 \quad 12.5 \quad 25$

ZO-2

GAPDH

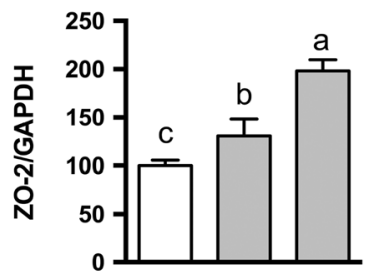

c

$\mathrm{CA}, \mu \mathrm{mol} / \mathrm{L} \quad 0 \quad 12.5 \quad 25$

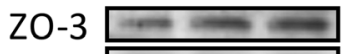

GAPDH

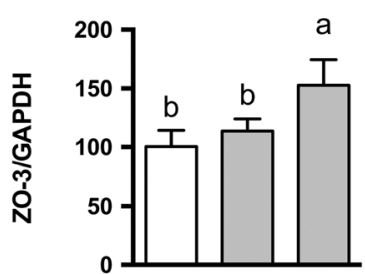

Fig. 3 Protein abundances for ZO-1 (a), ZO-2 (b), and ZO-3 (c) in IPEC-1 cells. Cells were cultured in the absence or presence of 12.5 or $25 \mathrm{mmol} / \mathrm{L}$ CA for $24 \mathrm{~h}$. Cells were collected and protein abundances were analyzed. Values are expressed as means $\pm \mathrm{SEM}, n=3$. Means without a common letter differ, $P<0.05$. CA, Cinnamicaldehye; IPEC-1, intestinal porcine epithelial cell line 1; ZO, zonula occludens

\section{Discussion}

In the present study, we have shown that CA, a key flavor compound in cinnamon essential oil, promoted the intestinal mucosal-barrier function as indicated by increased TEER and decreased paracellular permeability. Western blot analysis revealed that cells treated with $\mathrm{CA}$ had enhanced protein abundances for $\mathrm{TJ}$ proteins, such as claudin- 4 and scaffolding proteins. Moreover, the protein abundance for amino acid transporters, including $\mathrm{rBAT}$, LAT2, and $\mathrm{xCT}$, which are required for amino acid transport and absorption in enterocytes, were also enhanced by $\mathrm{CA}$ treatment. 


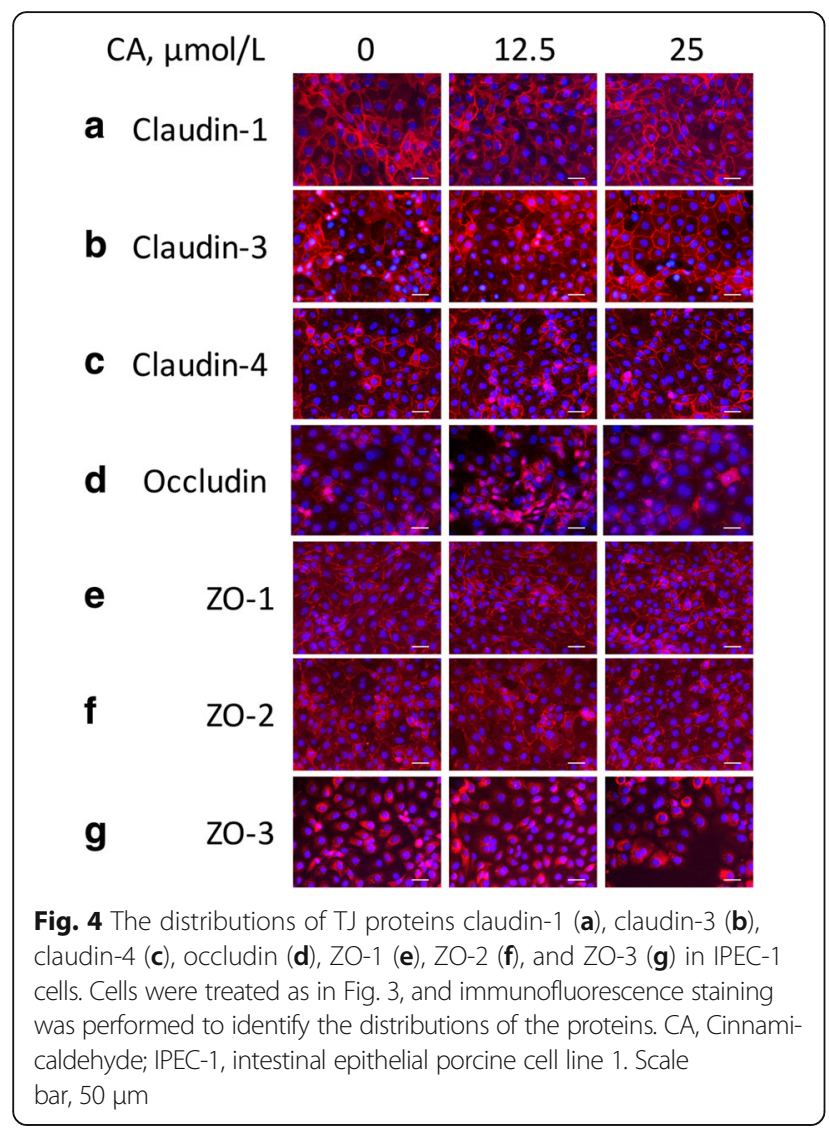

$\mathrm{CA}$, a natural compound isolated from the stem bark of Cinnamomum cassia, is widely used in food processing and animal diets due to its antioxidant, antimicrobial, and anti-diabetic attributes [2-4]. Studies in pigs, a widely used animal model for various disorders in humans, have demonstrated that CA supplementation enhances nutrient digestibility in pigs [10]. It remains largely unknown whether CA supplementation can have any effect on intestinal barrier integrity, thereby improving nutrient transport, absorption, and intracellular homeostasis.

To test this hypothesis, we first measured TEER, an indicator of intestinal epithelial integrity and permeability of intestinal epithelium. Incubation of the enterocyte with CA led to increased TEER and decreased FITC-dextran flux in intestinal porcine monolayers, suggesting a beneficial effect of CA on barrier function. Epithelial barrier function and paracellular permeability are primarily determined by epithelial TJ proteins $[29$, 30]. Transmembrane proteins (e.g., the claudin family protein, occludin) and peripheral membrane proteins (e.g., ZO-1, ZO-2 and ZO-3) have been identified as critical components of TJ proteins [31, 32]. Disruption of epithelial TJ proteins has been reported to be associated with multiple intestinal disorders [29, 33]. Consistently, restoration of $\mathrm{TJ}$ proteins by nutrients or prebiotics can improve mucosal barrier integrity and function in humans and animals [34]. We have recently found that dietary supplementation of glutamine prevented weanling stress-induced intestinal-mucosal barrier breakdown by augmenting TJ protein abundance [35], suggesting a functional role for amino acids in regulating mucosal barrier function.

In the present study, we found that CA regulates the protein abundance and cellular distributions of $\mathrm{T}$ ) proteins in intestinal cells. Specifically, the presence of $25 \mu \mathrm{mol} / \mathrm{L}$ CA led to enhanced protein abundances for claudin-4, ZO-1, ZO-2, and ZO-3, which are correlated well with augmented TEER values in IPEC-1 cells (Fig. 1). The claudin family proteins and $\mathrm{ZO}$ family proteins, play a crucial role in establishing cell-cell contacts and maintaining paracellular permeability [36, 37]. Recent studies have demonstrated that the reduction of claudin family proteins is strongly associated with intestinal barrier disruption in rodents $[38,39]$. The regulatory effects of CA on the protein abundance of TJ suggest that supplementation with CA might be a preventive strategy to maintain the appropriate function of the intestinal-mucosal barrier. Another novel finding of our study is that CA treatment led to the distributions of claudin-1 and claudin-3 to the cellular plasma membrane (Fig. 4a and b) without affecting their protein abundances (Fig. 2a and b). Thus, CA regulates both the abundance and localization of TJ proteins in enterocytes. Considering that the disruption of $\mathrm{TJ}$ is caused by various stresses and pathogens in pigs [40], supplementation of CA may provide an effective nutritional strategy to alleviate mucosal barrier dysfunction. At present, the underlying mechanisms responsible for this effect remain incompletely understood [31]. More research involving our IPEC-1 cell model is required to answer this question.

In addition to providing physical and functional barriers to prevent the entry of bacteria, endotoxins, and other harmful substances from entering the blood circulation, appropriate amounts of $\mathrm{TJ}$ proteins maintains the integrity of the intestinal epithelium and, therefore, are also required for the absorption of nutrients [15]. Amino acids released from the hydrolysis of dietary proteins and peptides in the lumen of the small intestine are transported across cell membranes by a complex system of multiple amino acid transporters [26-28]. A number of transporters have been identified on the apical surface of the mammalian small intestine that are responsible for the intestinal absorption of amino acids [26, 41, 42]. The defective intestinal uptake of amino acids leads to alterations in plasma amino acids, growth retardation, and the Hartnup disorder [26]. We have 

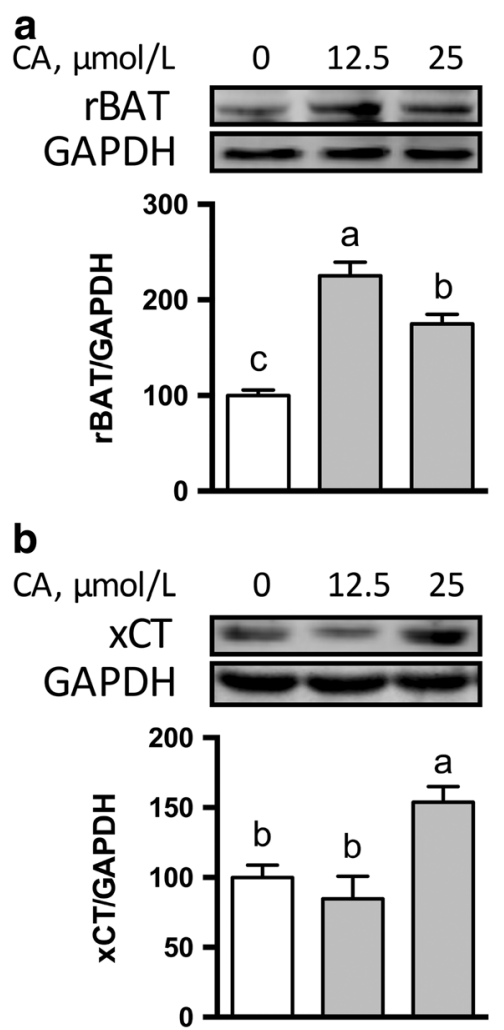

C
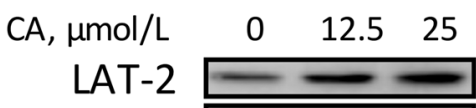

GAPDH

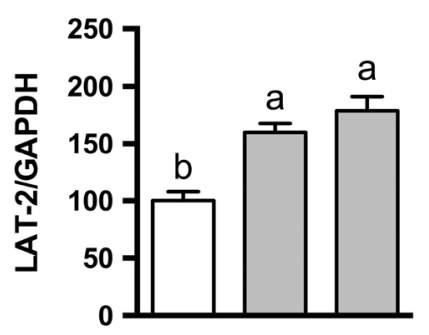

d

CA, $\mu \mathrm{mol} / \mathrm{L} \quad 0 \quad 12.5 \quad 25$
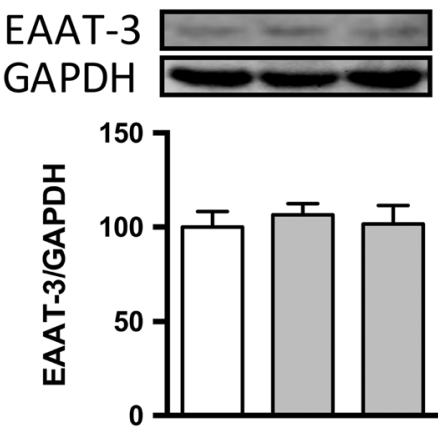

Fig. 5 Protein abundances for rBAT (a), xCT (b), LAT2 (c), and EAAT3 (d) in IPEC-1 cells. Cells were cultured in the absence or presence of 12.5 or $25 \mu \mathrm{mol} / \mathrm{L}$ CA for $24 \mathrm{~h}$. Cells were collected and protein abundances for amino acid transporters were analyzed. Values are expressed as means $\pm \mathrm{SEM}, n=3$. Means without a common letter differ, $P<0.05$. CA, Cinnamicaldehyde; IPEC-1, intestinal porcine epithelial cell line $1 ; Z O$, zonula occludens

found that CA increased protein abundances for amino acid transporters, including LAT2, rBAT, and $\mathrm{xCT}$ in porcine enterocytes. This is the first study showing that this flavor compound has the ability to up-regulate the expression of amino acid transporters in enterocytes. The enhanced protein abundance for amino acids transporters might promote the transport and absorption of amino acids, which, in turn, stimulates protein synthesis and contributes to the growth performance of pigs observed in previous studies [43, 44].

\section{Conclusions}

In summary, studies with porcine enterocytes have revealed that $\mathrm{CA}$ improved the intestinal epithelial barrier integrity, as indicated by increased TEER and decreased paracellular permeability. This beneficial effect of CA is accompanied by enhanced distribution of specific $\mathrm{TJ}$ proteins in intestinal epithelial cells. Importantly, the protein abundance for amino acid transporters was enhanced by CA. Further studies with animal model are needed to validate this beneficial effect of $\mathrm{CA}$ on intestinal barrier function observed in the present study. Supplementation with $\mathrm{CA}$ might be a potential nutritional strategy to improve the intestinal mucosal barrier function and nutrient absorption in neonatal piglets.

\section{Abbreviations}

CA: Cinnamic aldehyde; DMEM-F12: Dulbecco's modified Eagle's F12 Ham medium; EGF: Epidermal growth factor; FBS: Fetal bovine serum; HRP: Horseradish peroxidase; ITS: Insulin-transferrin-selenium; IPEC1: Intestinal porcine epithelial cells-1; TEER: Trans-epithelial electrical resistance; TJ: Tight junction; ZO: Zonula occludens

\section{Acknowledgements}

Not applicable.

Availability of data and materials

Data and material sharing applicable to this article.

\section{Funding}

This work was supported the National Natural Science Foundation of China (31572410, 31572412, 31625025), the 111 Project (B16044), the Program for New Century Excellent Talents in University (NCET-12-0522), the Agriculture and Food Research Initiative Competitive Grant from the USDA National Institute of Food and Agriculture (No. 2014-6701521770), and Texas A\&M AgriLife Research (H-8200). 


\section{Authors' contributions}

ZLW and GW designed research; KJS, YL, and RJW conducted research; ZLW, ZL. Dai, and GW analyzed data; KJS, and ZLW wrote the paper. ZLW and GW had primary responsibility for final content. All authors read and approved the final manuscript

\section{Competing interests}

The authors declare that they have no competing interests.

\section{Consent for publication}

Not applicable.

\section{Ethics approval and consent to participate} Not applicable.

\section{Author details \\ ${ }^{1}$ State Key Laboratory of Animal Nutrition, College of Animal Science and Technology, China Agricultural University, Beijing 100193, China. ${ }^{2}$ DadHank (Chengdu) Biotech Corp, Sichuan, China. ${ }^{3}$ Department of Animal Science, Texas A\&M University, College Station, TX 77843, USA. ${ }^{4}$ Department of Animal Nutrition and Feed Science, China Agricultural University, Beijing 100193, China.}

Received: 29 November 2016 Accepted: 29 May 2017

Published online: 16 August 2017

\section{References}

1. Bickers D, Calow P, Greim H, Hanifin JM, Rogers AE, Saurat JH, et al. A toxicologic and dermatologic assessment of cinnamyl alcohol, cinnamaldehyde and cinnamic acid when used as fragrance ingredients. Food Chem Toxicol. 2005;43(6):799-836

2. Anderson RA, Broadhurst $C L$, Polansky MM, Schmidt WF, Khan A Flanagan VP, et al. Isolation and characterization of polyphenol type-a polymers from cinnamon with insulin-like biological activity. J Agric Food Chem. 2004;52(1):65-70.

3. Matan N, Rimkeeree H, Mawson AJ, Chompreeda P, Haruthaithanasan V, Parker M. Antimicrobial activity of cinnamon and clove oils under modified atmosphere conditions. Int J Food Microbiol. 2006;107(2):180-5.

4. Singh G, Marimuthu P, de Heluani CS, Catalan CA. Antioxidant and biocidal activities of Carum Nigrum (seed) essential oil, oleoresin, and their selected components. J Agric Food Chem. 2006;54(1):174-81.

5. Dugoua JJ, Seely D, Perri D, Cooley K, Forelli T, Mills E, et al. From type 2 diabetes to antioxidant activity: a systematic review of the safety and efficacy of common and cassia cinnamon bark. Can J Physiol Pharmacol. 2007:85(9):837-47.

6. Wondrak GT, Villeneuve NF, Lamore SD, Bause AS, Jiang T, Zhang DD. The cinnamon-derived dietary factor cinnamic aldehyde activates the Nrf2dependent antioxidant response in human epithelial colon cells. Molecules. 2010;15(5):3338-55.

7. Cabello CM, Bair WB 3rd, Lamore SD, Ley S, Bause AS, Azimian S, et al. The cinnamon-derived Michael acceptor cinnamic aldehyde impairs melanoma cell proliferation, invasiveness, and tumor growth. Free Radic Biol med. 2009:46(2):220-31.

8. Kim BH, Lee YG, Lee J, Lee JY, Cho JY. Regulatory effect of cinnamaldehyde on monocyte/macrophage-mediated inflammatory responses. Mediat Inflamm. 2010;2010:529359.

9. Bae WY, Choi JS, Kim JE, Jeong JW. Cinnamic aldehyde suppresses hypoxia-induced angiogenesis via inhibition of hypoxia-inducible factor1alpha expression during tumor progression. Biochem Pharmacol. 2015; 98(1):41-50

10. Jiang XR, Awati A, Agazzi A, Vitari F, Ferrari A, Bento $H$, et al. Effects of a blend of essential oils and an enzyme combination on nutrient digestibility, ileum histology and expression of inflammatory mediators in weaned piglets. Animal. 2015;9(3):417-26.

11. Jamroz D, Wiliczkiewicz A, Wertelecki T, Orda J, Skorupinska J. Use of active substances of plant origin in chicken diets based on maize and locally grown cereals. Brit Poultry Sci. 2005;46(4):485-93.

12. Lee KW, Everts H, Kappert HJ, Frehner M, Losa R, Beynen AC. Effects of dietary essential oil components on growth performance, digestive enzymes and lipid metabolism in female broiler chickens. Brit Poultry Sci. 2003;44(3):450-7.
13. Lee J, Finn CE, Wrolstad RE. Comparison of anthocyanin pigment and other phenolic compounds of Vaccinium membranaceum and Vaccinium ovatum native to the pacific northwest of north AmericaJ Agr. Food Chem. 2004;52(23):7039-44.

14. Lee S, Han JM, Kim H, Kim E, Jeong TS, Lee WS, et al. Synthesis of cinnamic acid derivatives and their inhibitory effects on LDL-oxidation, acyl-CoA : cholesterol acyltransferase-1 and-2 activity, and decrease of HDL-particle size. Bioorg med Chem Lett. 2004;14(18):4677-81.

15. Jacobi SK, Odle J. Nutritional factors influencing intestinal health of the neonate. Adv Nutr. 2012;3(5):687-96.

16. Wang B, Wu G, Zhou Z, Dai Z, Sun Y, Ji Y, et al. Glutamine and intestinal barrier function.Amino Acids. 2015;47(10):2143-54.

17. Camilleri M, Madsen K, Spiller R, Greenwood-Van Meerveld B, Verne GN. Intestinal barrier function in health and gastrointestinal disease. Neurogastroenterol Motil. 2012;24(6):503-12.

18. Ulluwishewa D, Anderson RC, McNabb WC, Moughan PJ, Wells JM, Roy NC. Regulation of tight junction permeability by intestinal bacteria and dietary components. J Nutr. 2011;141(5):769-76.

19. Nusrat A, Turner JR, Madara JL. Molecular physiology and pathophysiology of tight junctions. IV. Regulation of tight junctions by extracellular stimuli: nutrients, cytokines, and immune cells. Am J Physiol Gastrointest Liver Physiol. 2000;279(5):G851-7.

20. Turner JR, Buschmann MM, Romero-Calvo I, Sailer A, Shen L. The role of molecular remodeling in differential regulation of tight junction permeability. Semin Cell dev Biol. 2014;36:204-12.

21. Haynes TE, Li P, Li X, Shimotori K, Sato H, Flynn NE, et al. L-glutamine or Lalanyl-L-glutamine prevents oxidant- or endotoxin-induced death of neonatal enterocytes. Amino Acids. 2009;37(1):131-42.

22. Wang W, Wu Z, Lin G, Hu S, Wang B, Dai Z, et al. Glycine stimulates protein synthesis and inhibits oxidative stress in pig small intestinal epithelial cells. J Nutr. 2014;144(10):1540-8.

23. Li N, DeMarco VG, West CM, Neu J. Glutamine supports recovery from loss of transepithelial resistance and increase of permeability induced by media change in Caco-2 cells. J Nutr Biochem. 2003;14(7):401-8.

24. Jiao N, Wu Z, Ji Y, Wang B, Dai Z, Wu G. L-glutamate enhances barrier and Antioxidative functions in intestinal porcine epithelial cells. J Nutr. 2015; 145(10):2258-64.

25. Wang B, Wu Z, Ji Y, Sun K, Dai Z, Wu G. L-glutamine enhances tight junction integrity by activating CaMK Kinase 2-AMP-activated protein Kinase signaling in intestinal porcine epithelial cells. J Nutr. 2016;146(3):501-8.

26. Broer S. Amino acid transport across mammalian intestinal and renal epithelia. Physiol rev. 2008;88(1):249-86.

27. Buddington RK, Elnif J, Puchal-Gardiner AA, Sangild PT. Intestinal apical amino acid absorption during development of the pig. Am J Physiol Regul Integr Comp Physiol. 2001;280(1):R241-7.

28. Steffansen B, Nielsen CU, Brodin B, Eriksson AH, Andersen R, Frokjaer S. Intestinal solute carriers: an overview of trends and strategies for improving oral drug absorption. Eur J Pharm Sci. 2004;21(1):3-16.

29. Clayburgh DR, Shen L. Turner JR.a porous defense: the leaky epithelial barrier in intestinal disease. Lab Investig. 2004;84(3):282-91.

30. Schneeberger $\mathrm{EE}, \mathrm{Lynch} \mathrm{RD}$. The tight junction: a multifunctional complex. Am J Physiol Cell Physiol. 2004;286(6):C1213-28.

31. Niessen CM. Tight junctions/adherens junctions: basic structure and function. J Invest Dermatol. 2007;127(11):2525-32.

32. Tsukita S, Furuse M, Itoh M. Multifunctional strands in tight junctions. Nat rev Mol Cell Biol. 2001;2(4):285-93.

33. Marchiando AM, Graham WV, Turner JR. Epithelial barriers in homeostasis and disease. Annu rev Pathol. 2010;5:119-44.

34. Turner JR. Intestinal mucosal barrier function in health and disease. Nat rev Immunol. 2009;9(11):799-809.

35. Wang H, Zhang C, Wu G, Sun Y, Wang B, He B, et al. Glutamine enhances tight junction protein expression and modulates corticotropin-releasing factor signaling in the jejunum of weanling piglets. J Nutr. 2015;145(1):25-31.

36. Markov AG, Veshnyakova A, Fromm M, Amasheh M, Amasheh S. Segmental expression of claudin proteins correlates with tight junction barrier properties in rat intestine. J Comp Physiol B. 2010;180(4):591-8.

37. Rahner C, Mitic LL, Anderson JM. Heterogeneity in expression and subcellular localization of claudins 2, 3, 4, and 5 in the rat liver, pancreas, and gut. Gastroenterology. 2001;120(2):411-22.

38. Lu Z, Ding L, Lu Q, Chen YH. Claudins in intestines: distribution and functional significance in health and diseases. Tissue Barriers. 2013:1(3): e24978. 
39. Yuan B, Zhou S, Lu Y, Liu J, Jin X, Wan H, et al. Changes in the expression and distribution of Claudins, increased epithelial apoptosis, and a Mannanbinding Lectin-associated immune response lead to barrier dysfunction in Dextran sodium sulfate-induced rat colitis. Gut and Liver. 2015:9(6):734-40.

40. Diesing AK, Nossol C, Danicke S, Walk N, Post A, Kahlert S, et al. Vulnerability of polarised intestinal porcine epithelial cells to mycotoxin deoxynivalenol depends on the route of application. PLoS One. 2011;6(2):e17472.

41. Christensen HN. Role of amino acid transport and countertransport in nutrition and metabolism. Physiol rev. 1990;70(1):43-77.

42. Dave MH, Schulz N, Zecevic M, Wagner CA, Verrey F. Expression of heteromeric amino acid transporters along the murine intestine. J Physiol. 2004;558(Pt 2):597-610.

43. Morales A, Buenabad L, Castillo G, Arce N, Araiza BA, Htoo JK, et al. Lowprotein amino acid-supplemented diets for growing pigs: effect on expression of amino acid transporters, serum concentration, performance, and carcass composition. J Anim Sci. 2015;93(5):2154-64.

44. Sun YL, Wu ZL, Li W, Zhang C, Sun K, Ji Y, et al. Dietary L-leucine supplementation enhances intestinal development in suckling piglets. Amino Acids. 2015;47(8):1517-25.

\section{Submit your next manuscript to BioMed Central} and we will help you at every step:

- We accept pre-submission inquiries

- Our selector tool helps you to find the most relevant journal

- We provide round the clock customer support

- Convenient online submission

- Thorough peer review

- Inclusion in PubMed and all major indexing services

- Maximum visibility for your research

Submit your manuscript at www.biomedcentral.com/submit 